\title{
Disposal of fly ash in the production of ash- concrete within the coal-watercoal cluster
}

\author{
T.V. Zommer ${ }^{*}$, E.V. Tkach, S.N. Chernyshev and V.L. Zommer \\ Moscow State University of Civil Engineering, Yaroslavskoe shosse, 26, Moscow, 129337, Russia
}

\begin{abstract}
Technologies for the disposal of industrial waste in the production of building materials are becoming particularly relevant in connection with the global trend of systematic reduction of the negative anthropogenic impact on the environment. Therefore, one of the goals of the pilot project of the innovative coal-watercoal cluster of housing and communal services is the utilization of ash waste from the combustion of coal-water fuel suspension in the production of building materials. The methodology of ash waste disposal consists in the modification of Portland cement with fine fly ash additives in the production of heavy concrete. As a result of the experiments, the authors proposed a recipe for a concrete mixture with ash waste additives. Tests of control samples of concrete and proposed samples of ash concrete with the addition of ash from the combustion of coal-water slurry were carried out. The brand of the proposed ash concrete in terms of compressive strength, corresponding to the design brand, is determined. Thus, we save the consumption of Portland cement as a binder, which is the most expensive component of concrete. At the same time, we dispose of man-made waste as a safe additive in the production of concrete with specified performance characteristics. The result obtained with the utilization of ash waste as an effective and safe aggregate for heavy concrete can be used in the implementation of a pilot project of an innovative coal-watercoal cluster of housing and communal services. Ash concrete with the addition of ash from the combustion of coal-water slurry can be recommended for use in industrial and civil construction.
\end{abstract}

\section{Introduction}

Industrial waste management is a particularly relevant topic for the global community. A large amount of industrial waste is disposed of, including in the production of building materials.

The project to create an innovative coal-watercoal cluster of housing and communal services includes the preparation of an innovative coal-water fuel suspension in boiler houses of housing and communal services, followed by combustion in specially equipped furnaces [1-3].

*Corresponding author: ZommerTV@mgsu.ru 
To reduce the impact of construction and housing on geospheres [4-6], it is necessary to dispose of ash waste obtained by burning the produced coal-water fuel suspension [7-14].

Therefore, the purpose of this study is to implement in practice the possibility of recycling ash waste in construction during the production of heavy concrete.

The theoretical and practical possibility of using ash waste from the burning of coalwater slurry, as well as other man-made waste, in the production of concrete has already been considered by some authors [15-26].

This article examines the issues of the formulation of ash concrete with the modification of Portland cement by the addition of ash waste from the combustion of coal-water slurry produced within the framework of the innovative coal-watercoal cluster of housing and communal services.

The hypothesis of the study was the assumption that the ash from the combustion of coal-water slurry can be an effective aggregate of heavy concrete, which allows to reduce the cost of its production by saving the binder (Portland cement) while maintaining the required strength.

The authors present the results of theoretical and practical studies that experimentally confirm the possibility of ash utilization as a fine additive in the production of heavy ashconcrete.

\section{Materials and methods}

In the article, the authors used the analysis of the literature data and the theoretical generalization of the methods. The methodology of theoretical and practical research is based on standardized methods of research, conducting and experimenting, and processing experimentally obtained data.

The material for experimental studies was fly ash collected after burning coal-water suspension. The methodology of ash waste disposal consists in the modification of Portland cement with fine ash additives in the production of heavy concrete.

These methods allowed the authors to make experimental samples of ash concrete, to test them on a press, to determine the brand of the proposed ash concrete. And also to develop practical recommendations for the processing of waste from the burning of coalwater fuel mixture in the production of heavy ash concrete within the coal-watercoal cluster of housing and communal services.

\section{Results}

The efficiency of the projected innovative coal-watercoal cluster of housing and communal services depends not only on obtaining an innovative water coal fuel mixture with specified rheological and environmental properties and its more complete combustion, but also on the possibility of recycling ash waste $[2,15]$.

After burning the resulting fine coal-water suspension with a sufficiently homogeneous granulometric composition, which provides stable rheological properties at the stage of preparation, storage and transportation, deep demineralization and reduction of harmful emissions due to almost one hundred percent combustion, fine waste is formed in the form of ash particles with a porous structure.

The burning of coal-water slurry and the collection of ash waste were carried out at the experimental site «Amaltea» in Izhevsk with the direct participation of the first author (Zommer T.V.).

The process of preparing a innovative coal-water fuel suspension by the method of water hammer with wet grinding of coal in an aqueous medium $[3,8,9,15]$ is reflected not 
only in a more complete combustion, but also in the formation of fine waste in the form of ash particles with a porous structure (figure 1).
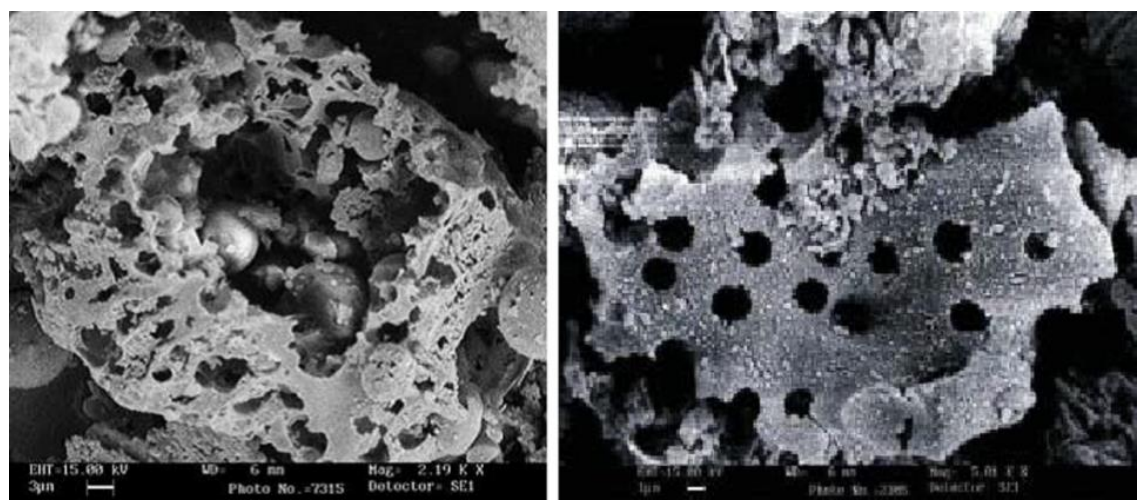

Fig. 1. Porous microstructure of ash particles from coal-water fuel combustion at the experimental site of «Amaltea» in Izhevsk $[8,15]$

In the framework of coal-watercoal cluster housing offered several options for disposing of fine ash from the combustion of coal-water fuel slurry (figure 2).

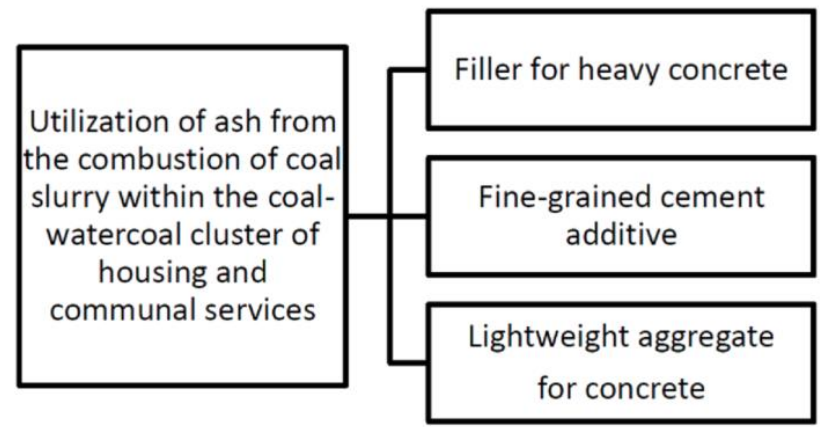

Fig. 2. Options for utilization of fine ash from the combustion of coal-water fuel slurry within the coal-watercoal cluster of housing and communal services

In this article, we consider the option of recycling fine ash from the combustion of coalwater fuel slurry as a filler of heavy concrete.

The optimal composition of concrete is considered to meet the technical requirements of construction and have the lowest cost. The most expensive component of concrete is cement. Therefore, even its partial replacement with waste from the combustion of coalwater fuel suspension is an important technical and economic task.

The study of the average technological sample of ash waste was carried out in the concrete laboratory of the I.V. Tananaev Institute of Chemistry and Technology of Rare Elements and Mineral Raw Materials of the KSC RAS in order to assess the effectiveness of their use as a micro-filler of concrete [10].

Ash waste from the combustion of watercoal slurry is mainly represented by the ash part. At the same time, the ash particle content of less than $0,315 \mathrm{~mm}$ is about $98 \%$.

The properties of ash from the combustion of coal-water slurry were determined taking into account the requirements of GOST 25818-91 «Fly ash of thermal power plants for concrete. Technical conditions».

The chemical composition of ash from the combustion of coal-water slurry is shown in Table 1. 
Table 1. Chemical composition of ash from the combustion of coal-water suspension [15]

\begin{tabular}{|c|c|c|c|}
\hline & Name of the chemical component & $\begin{array}{l}\text { Actual } \\
\text { value }\end{array}$ & $\begin{array}{c}\text { GOST requirements } \\
\text { 25818-91 / } \\
\text { 30108-94 (for item 12) }\end{array}$ \\
\hline 1 & Content $\mathrm{CaO}, \%$ & 4,0 & no more than 10 \\
\hline 2 & Content $\mathrm{MgO}, \%$ & 1,6 & no more than 5 \\
\hline 3 & $\begin{array}{l}\text { Content of sulfur and sulfuric acid compounds } \\
\text { in terms of на } \mathrm{SO}_{3}, \% \text { by weight }\end{array}$ & 0,36 & no more than 3 \\
\hline 4 & Content of alkaline oxides in terms of $\mathrm{Na}_{2} \mathrm{O}, \%$ & 2,95 & no more than 3 \\
\hline 5 & Mass loss during calcination & 0,88 & no more than 3 \\
\hline 6 & Specific surface area, $\mathrm{m}^{2} / \mathrm{\kappa g}$ & $450-480$ & not less than $150-300$ \\
\hline 7 & Residue on the sieve $008, \%$ & 12 & no more than $15-30$ \\
\hline 8 & Bulk density, кг/ $\mathrm{M}^{3}$ & 530 & - \\
\hline 9 & 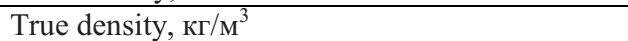 & 2220 & - \\
\hline 10 & Humidity, $\%$ & 0,12 & no more than 1 \\
\hline 11 & Impurities & нет & - \\
\hline 12 & $\begin{array}{l}\text { Effective specific activity of natural } \\
\text { radionuclides, } \mathrm{Bq} / \mathrm{kg}\end{array}$ & 200 & 370 \\
\hline
\end{tabular}

As can be seen from Table 1, ash waste meets the requirements for various types of concrete and reinforced concrete structures. Since the effective specific activity of natural radionuclides, equal to $200 \mathrm{~Bq} / \mathrm{kg}$, does not exceed the permissible value $(370 \mathrm{~Bq} / \mathrm{kg})$, the waste can be used for construction purposes without restrictions.

Laboratory tests were carried out on a series of samples prepared in compliance with the requirements of GOST 10180-2012 «Concrete. Methods for determining the strength of the control samples" from the working concrete mixture».

For the preparation of control samples-cubes of heavy concrete with a rib size of $150 \times 150 \times 150 \mathrm{~mm}$, we used: as a binder - Portland cement $500-\mathrm{D} 0$, as a filler - granite crushed stone and quartz sand.

In the proposed composition of the prototypes, a part of the Portland cement was replaced in the concrete mixture with ash from the combustion of a coal-water suspension in the amount of $20 \%$ of the binder weight. Forming of control and experimental samples in cubic forms took place on a vibrating table for 3 minutes.

For the control and proposed concrete mixes, the components listed in Table 2 were used.

Table 2. Components of the control and proposed concrete mixes

\begin{tabular}{|c|c|c|}
\hline \multirow[t]{2}{*}{ Components } & \multicolumn{2}{|c|}{ Consumption per $1 \mathrm{~m}^{3}$ of concrete $\mathrm{mix}, \mathrm{kg} / \mathrm{m}^{3}$} \\
\hline & Control composition & Proposed composition \\
\hline Portland cement $500-\mathrm{D} 0$ & 420 & 336 \\
\hline Quartz sand & 845 & 845 \\
\hline Granite crushed stone & 950 & \\
\hline Fly ash & - & 84 \\
\hline Water & 147 & 147 \\
\hline
\end{tabular}

The control samples-cubes with Portland cement (without additives) and the proposed samples with the addition of ash waste from the combustion of a water-coal mixture were kept under normal conditions after preparation until the brand strength was set for 28 days.

After 28 days, the control and proposed samples were tested for all quality indicators.

When determining the brand strength of concrete, we were guided by the requirements of regulatory documents: GOST 22690-2015 «Concrete. Determination of strength by mechanical methods of non-destructive testing», 28570-2019 «Concrete. Methods for determining strength from samples taken from structures», 18105-2018 «Concrete. Rules 
for the control and evaluation of strength», 10180-2012 «Concrete. Methods for determining the strength of control samples», which regulate the method of testing and processing the results.

We used a destructive test method, in which the control and proposed samples were successively subjected to destruction by means of a press. After each test, the values of the maximum compressive forces were recorded, and statistical processing was performed (Table 3).

Table 3. Test results of the control and proposed formulations after 28 days

\begin{tabular}{|c|c|c|c|c|}
\hline Compositions of the mixture & $\begin{array}{c}\text { Sample size, } \\
\text { mm }\end{array}$ & $\begin{array}{c}\text { Average } \\
\text { density, } \\
\mathbf{k g} / \mathbf{M}^{3}\end{array}$ & $\begin{array}{c}\text { Compressive } \\
\text { strength, } \\
\mathrm{MPa}\end{array}$ & $\begin{array}{l}\text { The strength } \\
\text { class of the } \\
\text { concrete in } \\
\text { compression }\end{array}$ \\
\hline $\begin{array}{l}\begin{array}{l}\text { Control } \\
\text { (without additives) }\end{array} \\
\end{array}$ & $150 \times 150 \times 150$ & 2362 & 26.1 & $\mathrm{~B} 20$ \\
\hline $\begin{array}{l}\text { Proposed } \\
\text { (with the addition of fly ash) }\end{array}$ & $150 \times 150 \times 150$ & 2420 & 27.5 & B20 \\
\hline
\end{tabular}

The analysis of the results in Table 3 showed that the proposed composition (with the addition of fly ash) has the same strength class as the control one (without additives).

Thus, we solve the problem of reducing the environmental burden on the environment by recycling man-made waste from the combustion of coal-water suspension (fly ash) as a safe additive in the production of concrete with specified performance characteristics.

At the same time, there is a significant saving of up to $20 \%$ of the consumption of the most expensive component of concrete - binder (Portland cement).

The obtained result can be used during the implementation of the project of the coalwatercoal cluster of housing and communal services in the utilization of ash from the combustion of coal-water fuel as an effective and safe filler for heavy concrete.

Also, thanks to the conducted research, it becomes possible to increase the resource efficiency of coal-watercoal technology. And in general, environmental and technological indicators are improving as part of the creation of a pilot site for an innovative coalwatercoal cluster of housing and communal services [2, 3].

\section{Conclusions}

The study conducted within the framework of the project of the innovative coalwatercoal cluster of housing and communal services allowed us to confirm the hypothesis, answer the questions raised and draw the following conclusions:

1. the proposed formulation of heavy concrete with the modification of Portland cement with ash waste from the combustion of coal-water slurry allows the disposal of fly ash in heavy concrete while maintaining the design strength;

2. the assumption that the ash from the combustion of coal - water slurry is an effective aggregate of heavy concrete, which allows saving up to $20 \%$ of the most expensive component-binder (Portland cement), is experimentally confirmed);

3. the results obtained allow us to develop practical recommendations for the use of waste from the combustion of water-coal slurry in the production of heavy-ash concrete for construction within the coal-watercoal cluster of housing and communal services.

The reported study was funded by RFBR, project number 19-35-90135. 


\section{References}

1. Tatyana Zommer and Sergey Chernyshev, Innovative geotechnologies is the key to geoenvironmental sustainability of urban areas by reducing the load and control techno-landscapes on the example of innovative water-coal technologies. MATEC Web of Conferences, 5, 03011, DOI: 10.1051/matecconf/20168603011 (2016)

2. TV Zommer and SN Chernyshev, Concept of management of the technolandscapes through the creation of innovative coal-watercoal clusters, XXIX R-P-S Seminar 2020, Wroclaw, Poland, IOP Conference Series: Materials Science and Engineering, 1015, 012054, doi:10.1088/1757-899X/1015/1/012054 (2021)

3. Zommer T.V., Chernyshev S.N. Use of natural the fracture of coal under the regulatory impact of water hammer in the coal-watercoal cluster of utilities sector, MATEC Web of Conferences (2021)

4. Trubetskoy K.N., Galchenko Y.P. Naturelike mining technologies: prospect of resolving global contradictions when developing mineral resources of the lithosphere, Herald of the Russian Academy of Sciences, 87, 4, 378-384 (2017)

5. Trubetskoy K.N. et al, RU $2684647 \mathrm{C} 1$ Method for controlling the geomechanical state of a rock mass (2018)

6. Ilyichev V., Emelyanov S., Kolchunov V. and Bakaeva N. About the dynamic model formation of the urban livelihood system compatible with the biosphere, Applied Mechanics and Materials, 725-726, 1224-1230 (2015)

7. Murko V.I., Khyamyalyainen, V.A., Baranova, M.P. The creation of a low-capacity boiler plant on coal-enrichment waste, International Science and Technology Conference "EastConf", EastConf 8725397 (2019)

8. Arkhipkin O.O., Morozov A.G. Modern approaches to the use of coal-water fuel, Ecological Bulletin of Russia, 11, 20-25 (2011)

9. Morozov A.G., Korenyugina N.V. Hydroimpact technologies in the production of watercoal fuel, Energy Safety and Energy Economy, 2, 12-15. (2010)

10. Zhao Z.-X., Lv W., Li R.-Y. Wang X.-H., Zhang D.-L. Papermaking waste water resource recovery- a new approach of preparation of coal water slurry, Applied Mechanics and Materials, 274, 87-90 (2013)

11. Li X., Liu J., Qwin J., Lui Y., Qu Y., Zang R. Dissolution behavior of a novel composite fiber made from blast furnace slag, Journal Construction and Building Materials, 206, 2019, 442-448

12. Osintsev K.V., Prikhodko I.S. Application of linear programming techniques to optimize the choice of coal and water coal fuel, Journal of Physics: Conference Series, 1333(4), 042025 (2019)

13. Du, Q., Liu, X., Wang, W., Zhong, J., Wang, S. Dynamic response of coal under impact load after supercritical $\mathrm{CO}_{2}$-water-coal interaction, Meitan Xuebao/Journal of the China Coal Society 44(11), 3453-3462 (2019)

14. Gorlov, E.G., Andrienko, V.G., Shpirt, M.Y. Gasification of Ultrafine Coal-Water Suspensions, Solid Fuel Chemistry, 53(6), 347-351 (2019)

15. Krasheninnikov O.N., Belogurova T.P., Maltzev L.I. Ash waste of burnt coal-water fuel as a concrete componen, Iindustrial ecology, 1 (81), 49-57 (2013)

16. Badur S., Chaudhary R. Utilization of hazardous wastes and by-products as a green concrete material through S/S process: A review, Reviews on Advanced Materials Science, 17(1-2), 42-61 (2008)

17. Zakharevich, Y.S., Strizhak, P.A. Technoeconomic Prerequisites for Use of WaterCoal-Organic Chemical Slurry Fuels in Large Power Plants, Chemical and Petroleum Engineering, 53(5-6), 412-419 (2017) 
18. Tkach, E.V., Temirkanov, R.I. Modified heavy concrete based on activated microsilica for sleepers of high-speed highways, IOP Conference Series: Materials Science and Engineering, 896(1), 012093 (2020)

19. Tkach, E., Rakhimov, A. Porous fillers for light concrete from technogenic raw materials, IOP Conference Series: Materials Science and Engineering, 365(3), 032014 (2018)

20. Carević, I., Serdar, M., Štirmer, N., Ukrainczyk, N. Preliminary screening of wood biomass ashes for partial resources replacements in cementitious materials, Journal of Cleaner Production, 229, c. 1045-1064 (2019)

21. Baskaran, K., Jayakody, J.R.U.C., Sandaruwan, M.A.R. Study on Strength and Durability of Cellular Cement-Fly Ash Blocks, MERCon Proceedings, International Multidisciplinary Moratuwa Engineering Research Conference, 5, 8818683, 31-36 (2019)

22. Lee, J.W., Choi, S.-H., Kim, K., Moon, B.-K. Variations in heavy metal analytical results and leaching characteristics of coal ash recycled concretes according to sample crushing methods, Economic and Environmental Geology, 51(5), 429-438 (2018)

23. Lee, J., Choi, S.-H., Kim, K., Kim, S.-H., Moon, B.-K. A study on changes in heavy metal contents in concrete prepared using coal ashes, Economic and Environmental Geology, 51(4), 371-379 (2018)

24. Saha, A.K., Sarker, P.K. Sustainable use of ferronickel slag fine aggregate and fly ash in structural concrete: Mechanical properties and leaching study, Journal of Cleaner Production, 162, 438-448 (2017)

25. Lederer, J., Trinkel, V., Fellner, J. Wide-scale utilization of MSWI fly ashes in cement production and its impact on average heavy metal contents in cements: The case of Austria, Waste Management, 60, 247-258 (2017)

26. Kadir, A.A., Hassan, M.I.H., Jamaluddin, N., Abdullah, M.M.A.B. Properties and Leachability of Self-Compacting Concrete Incorporated with Fly Ash and Bottom Ash, IOP Conference Series: Materials Science and Engineering, 133(1),012039 (2016) 